\title{
MUZYKA JAKO NARZĘDZIE KREOWANIA WRAŻEŃ KLIENTA W PUNKIE SPRZEDAŻY DETALICZNEJ
}

\begin{abstract}
Subiektywne odczucia klientów są jednym z głównych czynników wpływających na decyzję zakupu. Co więcej na podstawie badań można stwierdzić, że często mogą one być ważniejsze przy podejmowaniu decyzji niż jakość, cena czy też marka produktu. Pozytywne odczucia można wywołać między innymi poprzez stworzenie miłej atmosfery w miejscu sprzedaży, atrakcyjną witrynę sklepową oraz odpowiednią ekspozycję produktów na półkach. Według badań dwie trzecie decyzji, które podejmują konsumenci ma miejsce w punkcie handlowym. Co więcej, ponad 50\% klientów jest skłonnych zostać w sklepie dłużej, jeżeli atmosfera panująca w sklepie im odpowiada ${ }^{3}$. Atmosfera może być kreowana między innymi poprzez muzykę, zapach, oświetlenie czy barwy.

$\mathrm{W}$ artykule przedstawiono wybrane narzędzie marketingu sensorycznego - audiomarketing. Szczególną uwagę zwrócono na wykorzystanie muzyki w punkcie sprzedaży detalicznej. Podjęto próbę ustalenia, w jaki sposób muzyka wpływa na zachowanie klienta w sklepie. W pierwszej części przedstawiono podstawy teoretyczne dotyczące marketingu sensorycznego. Następnie zaprezentowano wyniki badania pierwotnego i badan wtórnych dotyczących zachowania klienta w sklepie pod wpływem muzyki.

Na podstawie przeprowadzonych analiz można stwierdzić, ze odpowiednie odziaływanie na zmysł słuchu przekłada się na decyzje zakupowe klienta. Obecnie klienci oczekują, że zakupy będą dla nich przyjemnością, rozrywką, miło spędzonym czasem wolnym. To właśnie za pomocą muzyki detaliści mogą stworzyć odpowiednią atmosferę w placówkach handlowych, wpłynąć na emocje klienta, sprawić, że czas pobytu w sklepie zostanie wydłużony, klient wyda więcej pieniędzy oraz zapamięta dane miejsce.
\end{abstract}

Słowa kluczowe: marketing sensoryczny, audiomarketing, zachowanie klienta

\section{WPROWADZENIE}

Przedsiębiorstwa działające w sektorze handlu szukają coraz to efektywniejszych metod, dzięki którym zwiększyłyby się ich zyski płynące z zakupów konsumentów. Jedną z nich jest wywołanie określonych zachowań konsumentów poprzez stymulację zmysłów klienta. Marketing sensoryczny (zmysłów) nabiera coraz większego znaczenia, ponieważ

${ }^{1}$ Dr Agnieszka Zielińska (autor korespondencyjny), Katedra Marketingu, Wydział Zarządzania, Politechnika Rzeszowska, Al. Powstańców Warszawy 8, 35-959 Rzeszów; e-mail: agaz@prz. edu.pl

2 Nikola Koy, lic., Wydział Zarządzania, Politechnika Rzeszowska, Al. Powstańców Warszawy 8, 35-959 Rzeszów.

${ }^{3}$ Atmosfera w sklepach ma coraz większe znaczenie, http://www.marketing-news.pl/message. php?art=27504 (dostęp: 22.12.2017 r.). 
odpowiednie odziaływanie na zmysł słuchu, węchu i wzroku przekłada się na decyzje zakupowe klienta. Bowiem za pomocą marketingu zmysłów można poprawić percepcję oraz procesy pamięciowe klienta, a tym samym sprawić, że klient łatwiej zapamiętuje daną markę i do niej powraca. Dzięki doświadczeniom zmysłowym w umyśle klienta można stworzyć wizerunek danej firmy. W punktach detalicznych na zmysły konsumentów można oddziaływać poprzez wykreowanie odpowiedniej atmosfery, w której skład wchodzą: muzyka, oświetlenie, kolorystyka czy też zapach.

$\mathrm{W}$ artykule przedstawiono wybrane narzędzie marketingu sensorycznego, tj. muzykę (audiomarketing). Szczególną uwagę zwrócono na wykorzystanie muzyki w punkcie sprzedaży detalicznej. W tym celu dokonano przeglądu literatury przedmiotu dotyczącej zachowań konsumentów oraz marketingu sensorycznego. W artykule wykorzystano również wyniki badania pierwotnego oraz badań wtórnych dotyczących wspomnianych zagadnień. Celem artykułu jest identyfikacja wpływu muzyki w punktach detalicznych na zachowanie konsumentów. W pierwszej części przedstawiono podstawy teoretyczne dotyczące marketingu sensorycznego oraz zachowań nabywców w miejscu sprzedaży. Następnie zaprezentowano wyniki badania pierwotnego i badań wtórnych dotyczących zachowania klienta w sklepie pod wpływem muzyki.

\section{ISTOTA MAREKTINGU ZMYSŁÓW}

Marketing sensoryczny, zwany też marketingiem pięciu zmysłów jest koncepcją, opierającą się na: słuchu, smaku, wzroku, węchu oraz dotyku. Jego podstawowym celem jest wzbogacenie procesu percepcji produktu oferowanego do sprzedaży w taki sposób, aby wywołać pozytywne emocje i nakłonić klienta do zakupu4. Marketing sensoryczny to działania marketingowe, które w rozważny sposób angażują zmysły potencjalnych klientów, dzięki czemu możliwe jest nadanie marce wyjątkowego indywidualnego charakteru, wyróżniając ją tym samym na tle innych firm ${ }^{5}$. Zgodnie z definicją American Marketing Association marketing sensoryczny to techniki marketingowe, których celem jest kuszenie klienta przy wykorzystaniu jego zmysłów, aby wpłynąć na jego emocje i zachowanie ${ }^{6}$.

Jak podkreśla Philip Kotler, dla klientów przy zakupie produktu nie są ważne jedynie opakowanie, reklama, obsługa posprzedażowa, lecz co ważniejsze - atmosfera miejsca, w której został on nabyty ${ }^{7}$. Atmosferę kształtują głównie zmysł wzroku (oświetlenie, kształty, kolory, wielkość), węchu (poczucie świeżości oraz zapach), dotyku (miękkość, gładkość, temperatura), słuchu (tonacja, głośność) ${ }^{8}$. Odpowiednie odziaływanie na wrażanie zmysłowe klienta może przekonać ich do zakupu oraz obejrzenia produktów ${ }^{9}$. Poprzez wywołanie nowych doświadczeń można pogłębić, zindywidualizować odczuwanie marki, a także zwiększyć zadowolenie konsumentów.

4 A. Pabian, Marketing sensoryczny, „Marketing i Rynek”, 2011, nr 1, s. 2.

5 A. Krishna, Sensory marketing: Research on the sensuality of products, Taylor \& Francis Inc, 2009 , s. 8.

${ }^{6}$ C. Valenti, J. Riviere, The concept of Sensory Marketing, 2008, s.8 http://www.diva-portal.org/ smash/get/diva2:238806/FULLTEXT01.pdf

7 Marketing zmystów atmosfera świąt, https://stosowana.wordpress.com/2010/12/11/marketingzmyslow-atmosfera-swiat/ (dostęp: 20.12.2017 r.).

8 P. Kotler, Atmospherics as a Marketing Tool, ,Journal of Retailing”, Vol. 49, 1973-1974, s. 51.

9 G.R. Foxall, R.E. Goldsmith, Psychologia konsumenta dla menedżera marketingu, Warszawa 1998, s. 232. 


\section{ZACHOWANIE KLIENTA W SKLEPIE POD WPLYWEM MUZYKI}

Konsumentem jest osoba fizyczna, która dokonuje wyboru, nabywa i spożywa usługi lub dobra, kierując się swoim dochodem, preferencjami, przyzwyczajeniami oraz tradycjami $^{10}$. Literatura przedmiotu przedstawia dużą liczbę różnych definicji zachowania konsumentów. Każda z nich odnosi się do różnych jego aspektów. Przykładowo według Jamesa F. Engela, Rogera D. Blackwella i Paula W. Miniarda pod pojęciem zachowania konsumentów rozumie się ogół działań związanych z uzyskiwaniem i użytkowaniem produktów i usług oraz dysponowaniem nimi, wraz $\mathrm{z}$ decyzjami poprzedzającymi i warunkującymi te działania ${ }^{11}$. Zachowania konsumentów odnoszą się do konsumpcji, która jest rozumiana jako proces zaspokajania potrzeb. Będąc jego odzwierciedleniem, ujmowane są jako ciąg reakcji, odpowiadający na konkretne bodźce - emocje oraz instynkty. One zaś skłaniają ludzi do tego, aby zaspokoili swoje potrzeby ${ }^{12}$. Jednym ze sposobów wpływania na decyzje zakupowe klienta poprzez emocje jest tworzenie odpowiedniej atmosfery w punkcie sprzedaży między innymi poprzez wykorzystanie muzyki.

Według badań dwie trzecie decyzji, które podejmują konsumenci ma miejsce w punkcie handlowym ${ }^{13}$. Co więcej, w Raporcie Open Research "Shoppers Perspective 2017" zwrócono uwagę na rosnący odsetek osób, które zaniechają zakupów planowanych na rzecz nieplanowanych (wzrost nastąpił o 6\%) ${ }^{14}$. Młodym ankietowanym w wieku 18-30 lat często zdarza się dokonywać zakupów pod wpływem impulsu (44,3\%). Tylko $4,5 \%$ tych osób nigdy nie zdarzyło się zrobić tego typu zakupów ${ }^{15}$. Wyniki te korespondują z badania TNS OBOP, z których wynika, że to właśnie ludzie młodzi najczęściej dokonują zakupów nieplanowanych ${ }^{16}$. Młodzi konsumenci mogą być bardziej podatni na czynniki wpływające na ich decyzje zakupu w miejscu sprzedaży oraz są oni bardziej spontaniczni, a ich proces decyzyjny zajmuje w tych przypadkach krótki czas. Na podstawie otrzymanych wyników badania można stwierdzić, że oprócz czynników cenowych, respondenci wskazywali, że duży wpływ na dokonanie decyzji zakupu pod wpływem impulsu miały takie elementy jak: muzyka, oświetlenie, zapach, kolorystyka, dobra ekspozycja produktu czy witryna sklepowa ${ }^{17}$.

${ }^{10}$ I. Altkorn, T. Kramer, Leksykon marketingu, Warszawa, 1998, s. 120.

${ }^{11}$ L. Rudnicki, Zachowanie konsumentów na rynku, Warszawa 2000, s. 14.

12 P. Łukasik, Marketing $w$ handlu detalicznym produktami spożywczymi, Lublin 2008, s. 13.

${ }^{13}$ POPAI Europe Consumer Buying Habits Study, s. 9, http://popai.com.au/wp-content/uploads/ Research\%20The\%20POPAI\%20Europe\%20Consumer\%20Buying\%20Habits\%20Study.pdf (dostęp: 22.12.2017 r.), POPAI 2014 Mass Merchant Shopper Engagement Study, s. 3 http:// memberconnect.shopassociation.org/HigherLogic/System/DownloadDocumentFile.ashx? DocumentFileKey=af210ce1-cdb1-d6fb-7306-8970cb321e60.

${ }^{14} \mathrm{http}: / /$ cluify.com/blog/zachowania-konsumentow-raport-shoppers-perspective-2017/ (dostęp: 16.07.2017 r.).

${ }^{15} \mathrm{Na}$ podstawie badania własnego. Badanie pierwotne zostało przeprowadzone metodą sondażu diagnostycznego, przy wykorzystaniu kwestionariusza ankiety za pomocą strony internetowej www.survio.com. Przedmiotem badania był wpływ muzyki na zachowanie klienta w sklepie. Badanie przeprowadzono na próbie 100 dorosłych mieszkańców województwa podkarpackiego. Zastosowano nielosowy dobór próby. Badanie przeprowadzono od grudnia 2016 r. do lipca 2017 roku

${ }^{16}$ Zakupy pod wptywem impulsu, http://www.egospodarka.pl/6860,Zakupy-pod-wplywemimpulsu,1,39,1.html (dostęp: 16.07.2017 r.).

${ }^{17} \mathrm{Na}$ podstawie badania własnego. 
Zmysł słuchu odgrywa istotną rolę w życiu człowieka. Pozwala on na odbieranie fal dźwiękowych, rozróżnianie głosów i muzyki, a przede wszystkim umożliwia komunikację $\mathrm{z}$ drugą osobą ${ }^{18}$. Jest on również kluczowy w audiomarketingu. Marketing dźwięku to wpływanie na postępowanie klientów za pomocą dźwięków, w celu stworzenia swoistej atmosfery w punkcie sprzedaży. Audiomarketing wykorzystywany jest nie tylko do stworzenia przyjemnej atmosfery w sklepie, ale także nadaje charakter produktom ${ }^{19}$.

Poprzez wywołanie nowych doświadczeń można pogłębić, zindywidualizować odczuwanie marki, a także zwiększyć zadowolenie konsumentów. Według badania Roberta Donovana oraz Johna Rossitera czas spędzany przez klientów w sklepie jest tym dłuższy im większa jest przyjemność oraz pobudzenie podczas zakupów. Przyjemność odczuwana w placówce ma także wpływ na interakcje ze sprzedawcami, chęć powrotu do danego sklepu, większe wydatki niż początkowo planowane, a także wielkość zakupów ${ }^{20}$. Zgodnie $\mathrm{z}$ wynikami badań konsumenckich, największą moc oddziaływania na klientów ma właśnie muzyka ${ }^{21}$. W związku $\mathrm{z}$ tym podjęto próbę ustalenia, w jaki sposób muzyka wpływa na zachowanie klienta w sklepie. Badanie pierwotne zostało przeprowadzone metodą sondażu diagnostycznego, przy wykorzystaniu kwestionariusza ankiety za pomocą strony internetowej www.survio.com. Przedmiotem badania był wpływ muzyki na zachowanie klienta $\mathrm{w}$ punktach detalicznych branży odzieżowej. Badanie przeprowadzono na próbie 100 dorosłych mieszkańców województwa podkarpackiego. Zastosowano nielosowy dobór próby. Badanie przeprowadzono od grudnia 2016 roku do lipca 2017 roku.

Na podstawie badania pierwotnego można stwierdzić, że $64 \%$ badanych było skłonnych zostać dłużej w sklepie, w którym panuje przyjemna atmosfera. Otrzymane wyniki korespondują z badania firmy Mood, na podstawie których wskazano, że ponad 50\% konsumentów pozostaje dłużej w sklepie, którego atmosfera ich satysfakcjonuje ${ }^{22}$. Muzyka może być jednym z elementów wpływającym na przyjemność zakupów. Respondenci stwierdzili, że muzyka w sklepie miała wpływ na zakup produktów $-69 \%$ wskazań ${ }^{23}$. Rozkład odpowiedzi przedstawiony został na wykresie 1. Podobne wyniki otrzymano w badaniu TNS OBOP, gdyż okazało się, że $72 \%$ konsumentów jest w stanie wydać więcej pieniędzy jeśli w punktach usługowych obecna jest muzyka, a 71\% osób woli odwiedzać lokale, gdzie w tle gra muzyka ${ }^{24}$. Co więcej, stosowanie odpowiedniej muzyki w miejscu sprzedaży powoduje zwiększenie liczby klientów o 30\% i wzrost sprzedaży o $15-28 \%$.

18 S. Musiał, Wszystko naraz, „Marketing w Praktyce” 2010, nr 10, s. 26.

${ }^{19}$ I. Michałkiewicz, Zmystowy marketing cz.1/dźwięk i muzyka, http://novapr.pl/blog/index. php/audiomarketing/ (dostęp: 21.03.2014 r.).

20 G.R. Foxall, R.E. Goldsmith, Psychologia konsumenta..., s. 232-233.

${ }^{21}$ Atmosfera w sklepach ma coraz większe znaczenie...

${ }^{22}$ Główne aspekty marketingu sensorycznego http://www.salesnews.pl/Article.aspx?id=1358 (dostęp: 16.07.2017 r.)

${ }^{23}$ Na podstawie badań pierwotnych.

${ }^{24}$ OBOP: muzyka pozytywnie wptywa na nastrój konsumentów, http://biznes.interia.pl/wiadomosci/ news/obop-muzyka-pozytywnie-wplywa-na-konsumentow,1496763,4199,strona,1,pst,31435514 (dostęp: 16.12.2017 r.).

${ }^{25}$ M. Walaszek, Dźwięki niedocenione, „Marketing w Praktyce” 2010, nr 10, s. 35-36. 


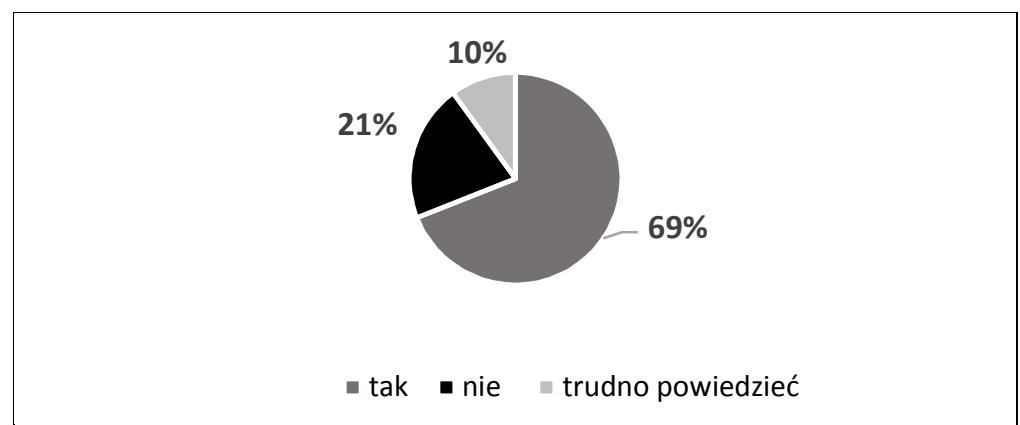

Wykres 1. Wpływ muzyki na zakup produktów

Źródło: opracowanie własne na podstawie badania pierwotnego.

$\mathrm{Z}$ innych badań prowadzonych w tym zakresie również płyną podobne wnioski, bo ponad $60 \%$ klientów uważa, że kupuje więcej w sklepach, w których była obecna muzyka. Menadżerowie również doceniają wpływ muzyki na klientów, ponad $80 \%$ z nich twierdzi, że obecność muzyki w miejscu sprzedaży wpływa pozytywnie na nastrój klientów. A co więcej, ponad $75 \%$ jest zdania, że klienci są skłonni kupić wtedy więcej produktów ${ }^{26}$. Natomiast po badaniu przeprowadzonym przez Dom Badawczy Maison można stwierdzić, że aż 91\% konsumentów preferuje dokonanie zakupów w placówce, w której można usłyszeć przyjemne dźwięki ${ }^{27}$. Badania wykazały, że zastosowanie wolniejszej muzyki w restauracjach powoduje zwiększenie wydawanych pieniędzy o $29 \%$, niż w przypadku restauracji, gdzie klientom towarzyszy szybsza muzyka ${ }^{28}$. Podobnie według przeprowadzonego na polskim rynku badania Millward Brown oraz IMS wynika, że konsumenci wracają częściej do sklepów, w których usłyszą przyjemną muzykę i w nich są w stanie zapłacić więcej za produkty ${ }^{29}$.

Skuteczny marketing sensoryczny przewiduje bardziej świadome zastosowanie muzyki zarówno pierwszego jak i drugiego planu. Muzyka drugiego planu, czyli tzw. tło muzyczne jest najczęściej muzyką instrumentalną o niewielkiej zmienności tempa, częstotliwości i poziomu głośności. Z kolei muzyka pierwszego planu zawiera słowa i jest zróżnicowana odnośnie do tempa, głośności i częstotliwości. Stosowanie zarówno muzyki pierwszego, jak i drugiego planu daje możliwość odniesienia marketingu do konkretnych grup klientów w zależności od płci czy wieku. Na podstawie badań można stwierdzić, że kobiety mają większą skłonność do wydawania pieniędzy, gdy w miejscu sprzedaży stosuje się muzykę drugiego planu. Mężczyźni zaś mogą nawet podwoić wysokość zakupów w przypadku gdy będzie im towarzyszyć muzyka pierwszego planu. Dodatkowo wykazano, że również wiek ma wpływ na odbiór muzyki. Okazało się, że osoby będące powyżej

${ }^{26}$ R.E. Milliman, Using Background Music to Affect the Behavior of Supermarekt Shoppers, ,Journal of Marketing" Vol. 46, Summer 1982, s. 86-87 [za:] B. Borusiak, Merchandising, Poznań 2009, s. 33-34.

${ }^{27}$ M. Książek, Muzyka w klienta. O audiomarketingu słów kilka, http://marketerplus.pl/teksty/ artykuly/muzyka-klienta-audiomarketingu-slow/ (dostęp: 18.07.2017 r.).

${ }^{28}$ K. Stasiuk, D. Maison, Psychologia konsumenta, Warszawa 2014, s. 103.

${ }^{29}$ Muzyka zadba o wizerunek $i$ atmosfere, http://nowymarketing.pl/a/10947,muzyka-zadba-o-wizerunek-i-atmosfere (dostęp: 25.07.2017 r.). 
50. roku życia są skłonne wydać więcej przy towarzyszącej im muzyce drugiego planu. Z kolei większe zakupy zrobiła grupa osób między 25. a 49. rokiem życia przy muzyce pierwszego planu ${ }^{30}$.

Muzyka wpływa również na postrzeganie upływu czasu przez człowieka. Wolna muzyka powoduje zwiększenie emocjonalnego sprzężenia zwrotnego sprawiając, że czas oczekiwania wydaje się krótszy. Zastosowanie muzyki o wolniejszym tempie jest korzystne dla przestrzeni usługowych, w których klient musi czekać na swoją kolej. Muzyka wpływa także na pobudzenie człowieka ${ }^{31}$. W związku z tym w badaniu szukano również odpowiedzi dotyczącej wpływu muzyki na ilość czasu spędzanego w sklepach odzieżowych przez klientów. Rozkład odpowiedzi przedstawia wykres 2.

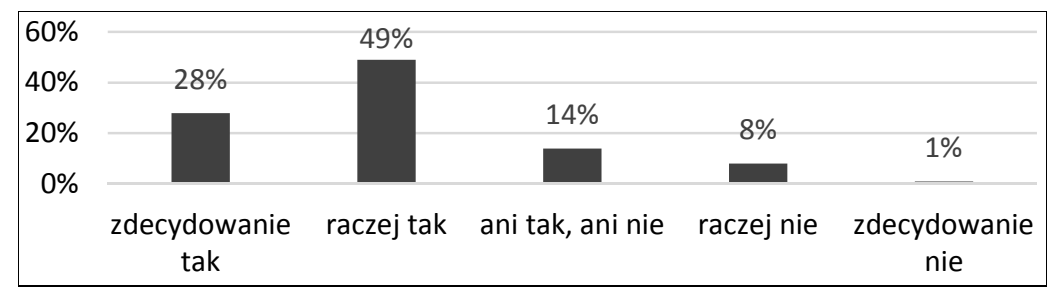

Wykres 2. Wpływ muzyki na ilość czasu spędzanego w sklepie

Źródło: opracowanie własne na podstawie badania pierwotnego.

Konsumenci spędzający swój czas w sklepach w większości byli świadomi tego, że tło muzyczne ma wpływ na czas jaki spędzają w sklepach. 77\% respondentów więcej czasu spędza w sklepie, gdzie słychać muzykę. Z badania Millward Brown oraz IMS wynika, że prawie $40 \%$ respondentów stwierdziło, że czas, który przebywają w miejscach sprzedaży jest dłuższy, gdy występuje w nich muzyka ${ }^{32}$. Muzyka sprawia, że ludzie się odprężają, a także likwiduje niezręczną ciszę w sklepie. Natomiast biorąc pod uwagę tempo poruszania się po sklepie to wolniejsza muzyka sprawia, że konsumenci wolniej poruszają się po miejscu sprzedaży, mogą bez pośpiechu podjąć decyzję o zakupie droższych produktów. Muzyka o tym tempie zalecana jest często do sklepów małopowierzchniowych. W sklepach wielkopowierzchniowych często słyszalna jest muzyka żywsza, bardziej energiczna. Ten typ muzyki sprawia, że klient porusza się szybciej, dzięki czemu jest bardziej skłonny do obejrzenia większej części sklepu oraz jego asortymentu ${ }^{33}$. W przypadku muzyki o wolniejszym tempie, poniżej spoczynkowego tempa bicia serca to jest ona również polecana w przypadku podejmowania decyzji o zakupie produktów drogich, gdyż sprawia ona, że klienci poruszają się wolniej po sklepie, w spokojnej atmosferze ${ }^{34}$. Nie bez znaczenie pozostaje również dopasowanie tempa muzyki, do pory dnia. Muzyka dynamiczna zalecana jest w porannych godzinach, w celu zaktywizowania klientów do zakupów. Natomiast melodie spokojniejsze powinny być emitowane w środku dnia, ponieważ najczęściej o tej porze zakupy robią osoby, którym nigdzie się nie spieszy. Z kolei popołudniem

${ }^{30}$ B. Hultén, N. Broweus, M. van Dijk, Marketing sensoryczny, Warszawa 2011, s. 77.

31 Tamże, s. 75-77.

${ }^{32}$ Muzyka zadba o wizerunek $i$ atmosferę...

${ }_{33}$ M. Gębarowski, Nowoczesne formy promocji, Rzeszów 2007, s. 71.

${ }^{34}$ B. Borusiak, Merchandisin..., s. 34-35. 
muzyka powinna być bardziej rytmiczna i szybsza, gdyż o tej porze w sklepach jest najwięcej klientów i dzięki temu można zwiększyć rotację klientów ${ }^{35}$. Zatem dzięki muzyce można wpłynąć na tempo poruszania się klienta po sali sprzedażowej.

Dowiedziono również, że muzyka wpływa w takim samym stopniu na emocjonalne odczucia zarówno osób wykształconych, jak i niewykształconych muzycznie. Co więcej, na podstawie badań przeprowadzonych w Stanach Zjednoczonych udowodniono, że wiele utworów muzycznych wywołuje podobne odczucia u słuchających oraz emocje; odnotowano tutaj dużą zgodność pomimo różnić płci, wieku czy zawodu ${ }^{36}$.

Bardzo ważnym powodem stosowania muzyki w punktach sprzedaży jest tzw. marketingteinment, czyli skłonność do zamieniania wszystkiego w rozrywkę. Socjologowie twierdzą, iż dzisiejsi konsumenci oprócz pożądanych produktów poszukują również zabawy, dlatego ważne jest stosowanie muzyki w punktach sprzedaży ${ }^{37}$.

\section{ZAKOŃCZENIE}

Placówki detaliczne na całym świecie coraz częściej projektowane są tak, aby przyciągnąć klientów i wpłynąć na ich decyzję zakupu. Można to osiągnąć dzięki wrażeniom zmysłowym, które docierają do konsumentów w sklepach. Mają one wpływ na to jak postrzegają klienci daną firmę, markę oraz na to jaką podejmą decyzję. Wrażenia te stymulowane są między innymi poprzez muzykę (audiomarketing).

$\mathrm{Na}$ podstawie przedstawionych wyników badań można stwierdzić, że muzyka ma wpływ na podjęcie decyzji zakupu, czas spędzony w sklepie czy też szybkość przemieszczania się po miejscu sprzedaży oraz samopoczucie klientów. Respondenci stwierdzili, że muzyka w sklepie wpływa na zakup produktów (69\% wskazań) oraz odpowiedzieli, że ma wpływ także na ilość czasu w nim spędzanego - zdecydowanie tak - $28 \%$ oraz raczej tak - 49\%. Biorąc pod uwagę szybkość przemieszczania się po sklepie, wskazano, że muzyka wolniejsza sprawia, iż konsumenci wolniej poruszają się po miejscu sprzedaży, łatwiej podjąć im decyzję zakupu droższego produktu, natomiast głośniejsza muzyka przyspiesza tempo klientów. Należy zatem przy wyborze muzyki kierować się charakterem sklepu oraz ich grupy docelowej.

Muzyka jest nieodłącznym elementem tworzącym atmosferę w placówkach handlowych, gdyż może ona sprawić, że klienci będą czuć się lepiej, zechcą zostać tam dłużej, wydadzą więcej pieniędzy i zarekomendują dane miejsce innym ${ }^{38}$. Wykazano, że w $65 \%$ przypadkach dźwięk wpłynął na możliwość zmiany nastroju u człowieka ${ }^{39}$.

Podsumowując, dzięki odpowiedniemu dobraniu tła muzycznego sklepy mogą wpłynąć na ilość pieniędzy wydawanych przez klientów, ich samopoczucie, lojalność czy szybkość przemieszczania się po powierzchni sprzedażowej. Wykorzystanie audiomarketingu w przestrzeniach sprzedażowych sprzyja pozyskiwaniu i utrzymywaniu klientów. Pozytywne doświadczenia osiągane dzięki zmysłowi słuchu odznaczają się w psychice

${ }^{35}$ L. Witek, Merchandising w matych i dużych firmach handlowych, Warszawa 2007, s. 67.

${ }^{36}$ M. Janiszewski, Muzykoterapia aktywna, Warszawa-Łódź 1993, s. 42-45 [za:] A. Bukowska Od emocji po fizjologię, czyli o oddziaływaniu muzyki na organizm człowieka, http://arteterapia.pl/ od-emocji-po-fizjologie-czyli-o-oddzialywaniu-muzyki-na-organizm-czlowieka/ (dostęp: 20.12.2017 r.).

${ }^{37}$ I. Michałkiewicz, Zmystowy marketing cz.1/dźwięk i muzyka...

${ }^{38}$ B. Hultén, N. Broweus, M. van Dijk, Marketing sensoryczny..., s. 76.

39 A. Kotowska, Marketing na 5 (zmystów), „Marketing w Praktyce” 2011, nr 7, s. 49. 
konsumenta sprawiając, że postrzega on daną firmę lub sklep w bardziej korzystny sposób i pozwalają przedsiębiorstwu na umocnienie pozycji wśród konkurencji. Marketing dźwięku jest zatem istotny w planowaniu działań marketingowych, jednak nie należy zapominać o pozostałych zmysłach ludzkich, które również wywołują wpływ na reakcje konsumentów. Największy wpływ na konsumenta posiadają przedsiębiorstwa, które stosują w połączeniu kilka elementów atmosfery, dobrze ze sobą skomponowanych np. zapach, muzykę, oświetlenie, kolorystykę. Należy jednak pamiętać, aby nie stosować zbyt dużo bodźców (przebodźcowanie), gdyż może to prowadzić do zmęczenia, wycofania klienta, zniechęcić go do danej marki i zakupów.

\section{Literatura}

[1] Altkorn I., Kramer T., Leksykon marketingu, PWE, Warszawa, 1998.

[2] Atmosfera w sklepach ma coraz większe znaczenie, http://www.marketing-news.pl/ message.php?art=27504

[3] Borusiak B., Merchandising, wyd. Uniwersytetu Ekonomicznego w Poznaniu, Poznań 2009.

[4] Bukowska A., Od emocji po fizjologię czyli o oddziaływaniu muzyki na organizm człowieka, http://arteterapia.pl/od-emocji-po-fizjologie-czyli-o-oddzialywaniu-muzyki-naorganizm-czlowieka/

[5] Foxall G.R., Goldsmith R.E., Psychologia konsumenta dla menedżera marketingu, wyd. PWN SA, Warszawa 1998.

[6] Gębarowski M., Nowoczesne formy promocji, Oficyna Wydawnicza Politechniki Rzeszowskiej, Rzeszów 2007.

[7] Główne aspekty marketingu sensorycznego, http://www.salesnews.pl/Article.aspx? $\mathrm{id}=1358$.

[8] Grzybowska-Brzezińska M., Rudzewicz A., Wptyw marketingu sensorycznego na decyzje konsumentów (znaczenie zmysłów), „Handel Wewnętrzny” 2013;6(347).

[9] http://cluify.com/blog/zachowania-konsumentow-raport-shoppers-perspective-2017/.

[10] Hultén B., Broweus N., van Dijk M., Marketing sensoryczny, Polskie Wydawnictwo Ekonomiczne, Warszawa 2011.

[11] Janiszewski M., Muzykoterapia aktywna, Wydawnictwo Naukowe PWN, WarszawaŁódź 1993.

[12] Kotler P., Atmospherics as a Marketing Tool, „Journal of Retailing”, Vol. 49, 1973-1974.

[13] Kotowska A., Marketing na 5 (zmystów), „Marketing w Praktyce” 2011, nr 7.

[14] Krishna A., Sensory marketing: Research on the sensuality of products, Taylor \& Francis Inc, 2009.

[15] Książek M., Muzyka w klienta. O audiomarketingu słów kilka, http://marketerplus.pl/ teksty/artykuly/muzyka-klienta-audiomarketingu-slow/.

[16] Łukasik P., Marketing $w$ handlu detalicznym produktami spożywczymi, Wydawnictwo Uniwersytetu Marii Curie-Skłodowskiej, Lublin 2008.

[17] Marketing zmystów atmosfera świąt https://stosowana.wordpress.com/2010/12/11/ marketing-zmyslow-atmosfera-swiat/.

[18] Michałkiewicz I., Zmysłowy marketing cz.l/dźwięk i muzyka, http://novapr.pl/blog/ index.php/audiomarketing/. 
[19] Musiał S., Wszystko naraz, „Marketing w Praktyce” 2010, nr 10.

[20] Muzyka zadba o wizerunek $i$ atmosfere, http://nowymarketing.pl/a/10947,muzyka-zadbao-wizerunek-i-atmosfere.

[21] OBOP: muzyka pozytywnie wptywa na nastrój konsumentów, http://biznes.interia.pl/ wiadomosci/news/obop-muzyka-pozytywnie-wplywa-na-konsumentow, 1496763,4199, strona, $1, p s t, 31435514$.

[22] Pabian A., Marketing sensoryczny, ,Marketing i Rynek” 2011, nr 1.

[23] POPAI Europe Consumer Buying Habits Study, http://popai.com.au/wpcontent/uploads/Research\%20The\%20POPAI\%20Europe\%20Consumer\%20Buying\% 20Habits\%20Study.pd.

[24] POPAI 2014 Mass Merchant Shopper Engagement Study, http://memberconnect. shopassociation.org/HigherLogic/System/DownloadDocumentFile.ashx?DocumentFile Key=af210ce1-cdb1-d6fb-7306-8970cb321e60.

[25] Rudnicki L., Zachowanie konsumentów na rynku, Polskie Wydawnictwo Ekonomiczne, Warszawa 2000.

[26] Stasiuk K., Maison D., Psychologia konsumenta, Wydawnictwo Naukowe PWN, Warszawa 2014.

[27] Valenti C., Riviere J., The concept of Sensory Marketing, 2008, http://www.diva-portal. org/smash/get/diva2:238806/FULLTEXT01.pdf.

[28] Walaszek M., Dźwięki niedocenione, „Marketing w Praktyce” 2010, nr 10.

[29] Witek L., Merchandising w matych i dużych firmach handlowych, wyd. C.H. Beck, Warszawa 2007.

[30] Zakupy pod wptywem impulsu, http://www.egospodarka.pl/6860,Zakupy-pod-wplywemimpulsu, 1,39,1.html.

\section{MUSIC AS A TOOL FOR CREATING CUSTOMER'S IMPRESSION AT A RETAIL OUTLET}

Subjective customer's impression is one of the major factors affecting their buying behavior. What is more, it can be even more influential than quality, price or brand according to recent research. Positive impression can be created by means of favorable atmosphere in the outlet, attractive window display or appropriate products' exposure on the shelves. According to the research two-thirds of customer decisions are made at the point of sales. Interestingly enough, over $50 \%$ of customers are willing to stay longer in a store if its atmosphere suits them. The latter can be created, among others, by proper music, scent, lighting or colors.

The aim of the article is to present one of the tools of sensory marketing, namely music (audio-marketing). Special attention is drawn to the significance of music at a retail outlet. It also attempts to identify ways in which music influences consumer behavior at the retailer. The first part of the paper provides theoretical background for the sensory marketing. The following parts present primary and secondary research outcomes regarding the issue of consumer behavior as influenced by the outlet's music.

Based on the research it can be concluded that sense of hearing, if affected properly, can have an effect on the buyer's decisions. Currently clients expect pleasure, entertainment and quality time when shopping. Thus, due to the very music retailers can create friendly and 
pleasant atmosphere, enable triggering customers' positive emotions, lengthening the time in store as well as increasing their shopping expenses. By means of music performed in the outlet, customers can remember the venue and associate it with high satisfaction.

Keywords: sensory marketing, audio-marketing, customer behavior

DOI: 10.7862/rz.2017.mmr.49

Tekst złożono w redakcji: grudzień 2017 r.

Przyjęto do druku: styczeń 2018 r. 